fructification of the larger marine algæ, with a consequent dissemination of spores in sufficient numbers to discolour the water. Whatever be the cause, however, the phenomenon is unusual, and has never been noticed by me before during eight years' residence in this part of South America.

State Geological Department, George Sheppard. Ecuador, Feb. 26

\section{Disease in Nature.}

IN the review of "The Science of Life", by Wells, Huxley, and Wells, there is a statement on p. 479 of NAture of Mar. 28, "we are prepared to defend the thesis that wild Nature (that is, apart from man's interference) is characteristically marked by exuberant positive health, while in eivilised society diseases are rife and sub-health is becoming almost normal !".

The statement is very attractive but, in so far as it refers to plants, is erroneous. We are only too well aware of the diseases of erops, but the factors which enter into the problem are not sufficiently understood for us to be able to distinguish clearly between the disease of a crop and the disease of individuals. It is a truism that there is a greater opportunity for the spread of disease in crops than in Nature; further, until recently, the cultivation of varieties of cropplants immune to a particular disease received scant attention.

The suggestion that trees, herbs, and shrubs growing in their natural habitats are invariably in good health is wide of the mark. While it is customary to assume the prevalence of fungal attack in tropical vegetation as visualised by popular writers, it is not perhaps realised that British flowering plants, probably without exception, are parasitised by one or more fungi. This parasitism is obviously of different degrees of severity, but it is so general that it has to be taken into account in intensive ecological investigation.

\section{British Museum (Natural History),} J. RAMSBOTTOM.

Cromwell Road, London, S.W.7, Mar. 30.

No one can doubt that infection with parasites and predatory microbes is common in wild Nature, both among plants and animals, but that is not tantamount to saying that disease is common. For disease, whether constitutional, environmental, functional, or parasitic, means disintegrative or deteriorative disturbances of the normal balanced metabolism of the organism. Speaking of animals some years ago, the late Sir Ray Lankester said that he knew with certainty of only one microbic disease in wild Nature - a bacterial disease of sandhoppers. Many parasites-if not most - seem to do little harm to their host, unless that becomes somehow enfeebled, for example, by man's over-crowding or over-sheltering. In many cases, the parasite establishes an innocuous modus vivendi with its host, though it may become harmful if man transfers it to a new hospitality. Moreover, many so-called parasites (the concept has become woolly) are really predatory organisms devouring the plant or animal from within, as a beast of prey does from without. Such predatory intruders may destroy the victim, but they do not bring about disease. All evidence from crops and plantations and the like must be excluded as irrelevant to my point that wild Nature is characteristically marked by exuberant positive health. But this is not to be taken as a dogmatic assertion that there is no disease in wild Nature, and Mr. Ramsbottom's expert caveat is very welcome.

The Reviewer.

\section{Extraction of Insulin.}

Is some earlier experiments it was found that insulin was precipitated quantitatively from commercial preparations by means of sulphosalicylic acid, and it appeared to us that this fact might form the basis of a method for the extraction of insulin which would obviate the use of large quantities of alcohol.

The following is an outline of the technique eventually employed : Bullock's pancreas, frozen immediately upon removal from the animal, is minced and allowed to thaw out in about two-thirds its weight of 20 per cent sulphosalicylic acid. After two hours the whole is filtered in a hydraulic press and the comparatively dry residue covered with acetone and left to dehydrate overnight in the cold. The almost water-free residue is now extracted in a Soxhlet with acetone and finally dried rapidly in a current of air at $40^{\circ}$. The active principle can now be extracted from the powdered fat-free residue by 75 per cent alcohol containing about 0.5 per cent of hydrochloric acid. The aqueous-alcoholic solution of insulin hydrochloride is concentrated in the usual way and the product precipitated with acetone. We obtained about $2 \mathrm{gm}$. per $\mathrm{kgm}$. of minced pancreas. A solution of $0.1 \mathrm{gm}$. of this substance produced, by subcutaneous injection in a $2 \mathrm{kgm}$. rabbit, hypoglycæmic convulsions in five and a half hours.

This method, whilst not entirely dispensing with the use of alcohol, requires much less than those in which fresh pancreas is extracted. We have not explored the conditions for obtaining maximum yield, nor have we the time to do so, but we give the foregoing details of a method which, we venture to think, may prove to be of interest to those more actively engaged in the manufacture of insulin.

$$
\text { P. G. Marshall. }
$$

B. P. Wiesner.

The Macaulay Laboratory,

Department of Animal Genetics,

The University, Edinburgh.

Identification of the Plant called ' Narthex'.

In NATURE of June 21, 1930, p. 920, Mr. Henry Balfour inquired as to the nature of the plant called 'narthex' by the present inhabitants of Lesbos. Through the kindness of Miss Winifred Lamb, who has been excavating there, it has been possible to identify it with Ferula communis, which is the giant fennel and, like a reed, has a hollow stem.

This, however, does not definitely solve the point at issue. Dr. G. F. Hill points out to me that some of the Cyrenaic coins have represented on them a Silphium, which is now extinct and which probably also had a hollow stem. For further information the Catalogue of the Greek Coins of Cyrenaica (British Museum), by E. S. G. Robinson (1927), p. ccli, can be consulted.

$$
\text { University College, }
$$

Gower Street, London, W.C.I.

THe definite identification of $\nu$ d $\rho \theta \eta \kappa a$, as used by modern Lesbians, with the giant fennel, Ferula communis, is interesting, and seems to dispose of Theodore Bent's identification of it with a reed. The dry pith inside the fennel stalk would, when ignited, continue to smoulder gently inside the protective casing of the stalk, which would prevent the wind causing the pith tinder to be too rapidly consumed. Bent's explanation of the $\nu a \rho \theta \eta \xi$ as serving to prevent the smouldering tinder "being blown out", is clearly erroneous. I desire to thank Mr. Eumorfopoulos for his note upon my communication of June 21, 1930.

\section{Henry Balfour.}

